\title{
Growing Degree Days and Heat Use Efficiency Influenced by Dates of Sowing and Irrigation Levels on Rainfed Chickpea
}

\author{
Medida Sunil Kumar*, M. Martin Luther, Ch. Pulla Rao, \\ K. L. Narasimha Rao and P. Ratna Prasad \\ Agronomy, Geospatial Technology Centre, RARS, ANGRAU, Lam, Guntur, \\ Andhra Pradesh, India \\ *Corresponding author
}

\begin{tabular}{|c|c|}
\hline & A B S T R A C T \\
\hline $\begin{array}{l}\text { Ke y w o r d s } \\
\text { Irrigation Levels, } \\
\text { Rainfed Chickpea }\end{array}$ & \multirow{3}{*}{$\begin{array}{l}\text { A field experiment was conducted during Rabi, } 2016-17 \text { on black soils to find the } \\
\text { influence of dates of sowing and irrigation levels on chickpea heat use efficiency } \\
\text { and heat units required to reach different phenophases. The chickpea crop required } \\
82 \text { to } 97^{\circ} \mathrm{C} \text { days at emergence, whereas to enter the reproductive stage (first } \\
\text { flower) crop required } 794 \text { to } 1073^{\circ} \mathrm{C} \text { days. The growing degree days required by } \\
\text { chickpea to reach maturity ranged from } 2066 \text { to } 2200^{\circ} \mathrm{C} \text { days. The phenophases, } \\
\text { emergence, and end pod were not influenced by irrigation levels. Irrigation levels } \\
\text { influenced growing degree days at physiological maturity and harvest. Delay in } \\
\text { sowing led to a decrease in heat use efficiency. }\end{array}$} \\
\hline Article Info & \\
\hline $\begin{array}{l}\text { Accepted: } \\
10 \text { July } 2020 \\
\text { Available Online: } \\
10 \text { August } 2020\end{array}$ & \\
\hline
\end{tabular}

\section{Introduction}

Chickpea is grown under wide agro-climatic conditions ranging from $10 \mathrm{~N}$ to $40 \mathrm{~N}$ latitudes in the northern hemisphere (Berger et al., 2006) and $27 \mathrm{~S}$ and $38 \mathrm{~S}$ latitudes in the Southern hemisphere (Imtiaz et al., 2011). Growing regions of chickpea can be broadly divided into two, non-tropical dry areas and semi-arid tropics (Imtiaz et al., 2011).

Chickpea becomes one of the promising rainfed rabi crop on black soils during the winter season in India and Andhra Pradesh in particular. Chickpea cultivation is solely dependent on the soil moisture reserve where planting is late during the recession of the main rainy season to escape the water logging conditions. Shorter cool and dry weather period prevailed between November to February favor the crop growth and development in this region. Delayed sowings force the crop to pass through warmer temperatures during the reproductive phase which is one of the major hindrances to optimum productivity.

Both temperature and moisture supply during the growing period had a strong influence on chickpea. The start of flowering in chickpea is 
dependent on photothermal conditions which is the main determinant for growth and development (Basu et al., 2009). Flower development is a crucial stage because fluctuations in weather conditions ultimately influence crop production. Optimum sowing date results in timely initiation of flowering by minimizing abiotic stress. The most vital step towards enhancing the yield of chickpea is to ensure that the phenology of the crop is well in line to the resources and constraints of crop growth and development (Summerfield et al., 1990).

Temperature is an important factor controlling crop growth and development by affecting a wide range of physiological processes and altering plant-water relationships (Zinn et al., 2010). Delayed sowings reduce the reproductive period in tropical regions (Ahmed et al., 2011), growing degree days required to physiological maturity (Chaitanya and Chandrika 2006, Sardar, 2009, Mukesh et al., 2010, Sugui and Sugui (2002)) and heat use efficiency (Mukesh et al., 2010). Irrigation delayed flowering and pod development irrespective of the date of sowing (Agrawal and Upadhyay, 2006). The variability in chickpea yield across the date of sowing was explained through temperature variation recorded during different growth stages (Agrawal and Upadhyay, 2006). An adverse effect of temperature can be compensated to some extent by the application of irrigation in late-planted conditions. Moisture stress is one of the main reasons for the timing of the onset of senescence in chickpea. Grain yield is significantly sensitive to water stress during the pod setting to grain development periods irrespective of soil texture (Jalota et al., 2006).

Optimizing sowing dates and deficit irrigation can minimize the exposure to temperature stress. By keeping in view the experiment was planned to study the Growing degree days and Heat use efficiency influenced by dates of sowing and irrigation levels on rainfed chickpea.

\section{Materials and Methods}

This study was carried out in Maddipadu village of Prakasam District, Andhra Pradesh, India during Rabi 2015-16 and 2016-17. The experimental site is located at an altitude of $11.0 \mathrm{~m}$ above MSL, 15 62` $\mathrm{N}$ latitude, 80 02 E longitude, and $25 \mathrm{~km}$ away from the Bay of Bengal in the Krishna Agro Climatic Zone of Andhra Pradesh.

The experimental site falls under semi-arid climatic conditions as per Thornthwaite's method of climate classification and Tropical savanna with dry summer as per Koppen's methods of climate classification.

The results of the soil analysis indicated that the soil was clay in texture $(45 \%)$, slightly alkaline in reaction (8.1), medium in organic carbon content $(0.51 \%)$, low in available nitrogen (201 kg ha ${ }^{-1}$ ), high in available phosphorus (95.5 kg ha-1) and potassium (86 $\mathrm{kg} \mathrm{ha}^{-1}$ ).

The chickpea variety, JG 11 (ICVV93954), used for the study is a popular bold seeded variety developed by ICRISAT in partnership with Jawaharlal Nehru Krishi Viswa Vidyalaya (JNKVV), Jabalpur, Madhya Pradesh.

The experiment was conducted in strip plot design replicated thrice in with three sowing windows as main plots viz., $\mathrm{D}_{1}$ : $2^{\text {nd }}$ Fortnight of October, $\mathrm{D}_{2}: 1^{\text {st }}$ Fortnight of November and $D_{3}$ : $2^{\text {nd }}$ Fortnight of November and eight irrigation levels of water with one control i.e., $\mathrm{I}_{1}=$ No irrigation, $\mathrm{I}_{2}=$ Irrigation with aerial water spray at pod filling stage (70-75 DAS) @ 5,000 $\mathrm{L} \mathrm{ha}^{-1}, \mathrm{I}_{3}=$ Irrigation with aerial 
water spray at pod filling stage (70-75 DAS) @ 10, $000 \mathrm{~L} \mathrm{ha}^{-1}, \mathrm{I}_{4}=$ Irrigation with aerial water spray at pod filling stage (70-75 DAS) (a) 15, $000 \mathrm{~L} \mathrm{ha}^{-1}, \mathrm{I}_{5}=$ Irrigation with aerial water spray at pod filling stage (70-75 DAS) @ 20, $000 \mathrm{~L} \mathrm{ha}^{-1}, \mathrm{I}_{6}=$ Irrigation with aerial water spray at maximum vegetative stage (3035 DAS) followed by pod filling stage (70-75 DAS)@5,000 L ha ${ }^{-1}, \mathrm{I}_{7}=$ Irrigation with aerial water spray at maximum vegetative stage (30-35 DAS) followed by pod filling stage (70-75 DAS) @ 10,000 L ha ${ }^{-1}, \mathrm{I}_{8}=$ Irrigation with aerial water spray at maximum vegetative stage (30-35 DAS) followed by pod filling stage (70-75 DAS) @ 15,000 L $\mathrm{ha}^{-1}, \mathrm{I}_{9}=$ Irrigation with aerial water spray at maximum vegetative stage (30-35 DAS) followed by pod filling stage (70-75 DAS) @ 20, $000 \mathrm{~L} \mathrm{ha}^{-1}$.

This study was carried out with specific objectives of heat use efficiency and no heat units required reaching each phenophases under the above main and sub-plot treatments. During the crop growth period, $36.1 \mathrm{~mm}$ of rainfall was recorded in 2015-16, and 262.8 $\mathrm{mm}$ received in 2016-17 against normal rainfall of $441 \mathrm{~mm}$.

The distribution of rainfall was highly in uneven is 2015-16 but cool and dry weather favored crop growth. Recommended package and practices were followed for crop management. Crop phenophases were recorded and growing degree-days (GDD) were determined as per Nuttonson (1955).

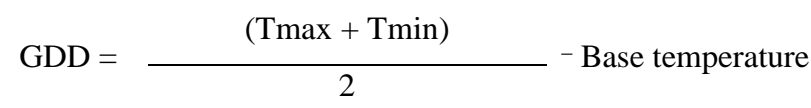

Where, Tmax and Tmin are the daily maximum and minimum temperature $\left({ }^{\circ} \mathrm{C}\right)$. The base temperature was taken $5^{\circ} \mathrm{C}$ for the analysis.

The HUE was worked using the formula and units for heat use efficiency is The HUE was worked using the formula and units for heat use efficiency is $\mathrm{kg} \mathrm{ha}^{-1 \mathrm{o}} \mathrm{C}^{-1}$ day $^{-1}$.

$$
\text { Heat use efficiency }(\mathrm{HUE})=\frac{\text { Seed yield }}{\text { Growing degree days }} \mathrm{X} 100
$$

\section{Results and Discussion}

The data on growing degree days required to reach different phenophases during rabi 201516 crop season presented in Table-1.

Among different dates of sowing, crop sown during the 2nd fortnight of October recorded the highest growing degree days to reach maturity followed by $1^{\text {st }}$ fortnight of November whereas the lowest was recorded with the $2^{\text {nd }}$ fortnight of November. The chickpea crop required 84 to $97 \mathrm{C}$ days at emergence, whereas to enter the reproductive stage (first flower) crop required 794 to 1073 $\mathrm{C}$ days. The growing degree days required by chickpea to reach maturity ranged from 2066 to $2188 \mathrm{C}$ days. The phenophases, emergence, and end pod were not influenced by irrigation levels. The response to irrigation levels was noticed with $\mathrm{I}_{8}$ and $\mathrm{I}_{9}$ treatments at the first flower and first pod stage and $\mathrm{I}_{9}$ treatment at first seed-stage during 2015-16 and superior to the rest of the treatments. Irrigation levels influenced growing degree days at physiological maturity and harvest. Higher heat units were registered with $\mathrm{I}_{5}, \mathrm{I}_{9}, \mathrm{I}_{4}$, and $\mathrm{I}_{8}$ treatments in descending order.

The perusal of data presented in Table-2 indicates a similar response to the dates of sowing in accumulation of growing degree days at different phenophases as in the 201516 crop season. The chickpea crop required 82 to $94 \mathrm{C}$ days at emergence, whereas to enter the reproductive stage (first flower) crop required 782 to $1064 \mathrm{C}$ days. The growing degree days required by chickpea to reach maturity ranged from 2122 to $2200 \mathrm{C}$ days. The phenophases, emergence, and end pod were not influenced by irrigation levels 
during 2016-17 also. Unlike the response to irrigation levels in the first year, $\mathrm{I}_{9}$ treatment registered higher growing degree days at the first flower, first pod, first seed, physiological maturity, and at harvest over other irrigation levels, Which was closely followed by $\mathrm{I}^{5}$ and $\mathrm{I}^{8}$ treatments at physiological maturity and harvest.

Table.1 Growing degree days $\left({ }^{\circ} \mathrm{C}\right.$ day) required to reach different phenophases as influenced by different dates of sowing and irrigation levels during Rabi 2015-16

\begin{tabular}{|c|c|c|c|c|c|c|c|}
\hline Treatment & Emergence & $\begin{array}{c}\text { First } \\
\text { flower }\end{array}$ & $\begin{array}{c}\text { First } \\
\text { Pod }\end{array}$ & $\begin{array}{l}\text { First } \\
\text { Seed }\end{array}$ & $\begin{array}{l}\text { End } \\
\text { pod }\end{array}$ & $\begin{array}{l}\text { Physiological } \\
\text { maturity }\end{array}$ & Harvest \\
\hline \multicolumn{8}{|l|}{ Dates of sowing } \\
\hline $2^{\text {nd }}$ Fortnight of October & 97 & 1073 & 1201 & 1334 & 1464 & 2025 & 2188 \\
\hline $1^{\text {st }}$ Fortnight of November & 85 & 920 & 1050 & 1254 & 1412 & 1976 & 2142 \\
\hline $2^{\text {nd }}$ Fortnight of November & 84 & 794 & 930 & 1260 & 1420 & 1891 & 2066 \\
\hline Mean & 89 & 929 & 1060 & 1283 & 1432 & 1964 & 2132 \\
\hline \multicolumn{8}{|l|}{ Irrigation levels as aerial water spray $\left(\mathrm{L} \mathrm{ha}^{-1}\right)$} \\
\hline$I_{1}=$ No irrigation & 89 & 923 & 1055 & 1288 & 1432 & 1952 & 2120 \\
\hline$I_{2}=$ Irrigation at 75 DAS @ 5,000 & 89 & 923 & 1055 & 1288 & 1432 & 1952 & 2120 \\
\hline$I_{3}=$ Irrigation at 75 DAS @ 10, 000 & 89 & 923 & 1055 & 1288 & 1432 & 1952 & 2120 \\
\hline $\mathbf{I}_{4}=$ Irrigation at 75 DAS @ 15, 000 & 89 & 923 & 1055 & 1288 & 1432 & 1973 & 2141 \\
\hline$I_{5}=$ Irrigation at 75 DAS @ 20,000 & 89 & 923 & 1055 & 1288 & 1432 & 1994 & 2163 \\
\hline$I_{6}=$ Irrigation at 35 and 75 DAS @ 5,000 & 89 & 923 & 1055 & 1288 & 1432 & 1952 & 2120 \\
\hline$I_{7}=$ Irrigation at 35 and 75 DAS @ 10,000 & 89 & 923 & 1055 & 1288 & 1432 & 1952 & 2120 \\
\hline$I_{8}=$ Irrigation at 35 and 75 DAS @ 15, 000 & 89 & 942 & 1068 & 1288 & 1432 & 1965 & 2133 \\
\hline$I_{9}=$ Irrigation at 35 and 75 DAS @ 20,000 & 89 & 960 & 1088 & 1307 & 1432 & 1987 & 2155 \\
\hline Mean & 89 & 929 & 1060 & 1283 & 1432 & 1964 & 2132 \\
\hline
\end{tabular}

Table.2 Growing degree days $\left({ }^{\circ} \mathrm{C}\right.$ day) required to reach different phenophases as influenced by different dates of sowing and irrigation levels during Rabi 2016-17

\begin{tabular}{|c|c|c|c|c|c|c|c|}
\hline Treatment & Emergence & $\begin{array}{l}\text { First } \\
\text { flower }\end{array}$ & $\begin{array}{l}\text { First } \\
\text { Pod }\end{array}$ & $\begin{array}{l}\text { First } \\
\text { Seed }\end{array}$ & $\begin{array}{l}\text { End } \\
\text { pod }\end{array}$ & $\begin{array}{l}\text { Physiological } \\
\text { maturity }\end{array}$ & Harvest \\
\hline \multicolumn{8}{|l|}{ Dates of sowing } \\
\hline $2^{\text {nd }}$ Fortnight of October & 94 & 1064 & 1195 & 1327 & 1452 & 2029 & 2200 \\
\hline $1^{\text {st }}$ Fortnight of November & 82 & 914 & 1041 & 1284 & 1417 & 1983 & 2161 \\
\hline $2^{\text {nd }}$ Fortnight of November & 88 & 782 & 924 & 1268 & 1439 & 1936 & 2122 \\
\hline Mean & 88 & 920 & 1053 & 1293 & 1436 & 1983 & 2161 \\
\hline \multicolumn{8}{|l|}{ Irrigation levels as aerial water spray $\left(\mathrm{L} \mathrm{ha}^{-1}\right)$} \\
\hline$I_{1}=$ No irrigation & 88 & 918 & 1052 & 1291 & 1436 & 1973 & 2150 \\
\hline$I_{2}=$ Irrigation at 75 DAS $@ 5,000$ & 88 & 918 & 1052 & 1291 & 1436 & 1973 & 2150 \\
\hline$I_{3}=$ Irrigation at 75 DAS @ 10,000 & 88 & 918 & 1052 & 1291 & 1436 & 1973 & 2150 \\
\hline$I_{4}=$ Irrigation at 75 DAS @ 15, 000 & 88 & 918 & 1052 & 1291 & 1436 & 1973 & 2150 \\
\hline$I_{5}=$ Irrigation at 75 DAS @ 20,000 & 88 & 918 & 1052 & 1291 & 1436 & 1995 & 2175 \\
\hline$I_{6}=$ Irrigation at 35 and 75 DAS @ 5,000 & 88 & 918 & 1052 & 1291 & 1436 & 1973 & 2150 \\
\hline$I_{7}=$ Irrigation at 35 and 75 DAS $@ 10,000$ & 88 & 918 & 1052 & 1291 & 1436 & 1973 & 2150 \\
\hline$I_{8}=$ Irrigation at 35 and 75 DAS @ 15, 000 & 88 & 918 & 1052 & 1291 & 1436 & 1995 & 2175 \\
\hline$I_{9}=$ Irrigation at 35 and 75 DAS @ 20,000 & 88 & 937 & 1065 & 1311 & 1436 & 2017 & 2199 \\
\hline Mean & 88 & 920 & 1053 & 1293 & 1436 & 1983 & 2161 \\
\hline
\end{tabular}


Fig.1 Heat use efficiency $\left(\mathrm{kg} \mathrm{ha}^{-1}{ }^{\circ} \mathrm{C}^{-1} \mathrm{day}^{-1}\right)$ as influenced by different dates of sowing and irrigation levels during 2015-16

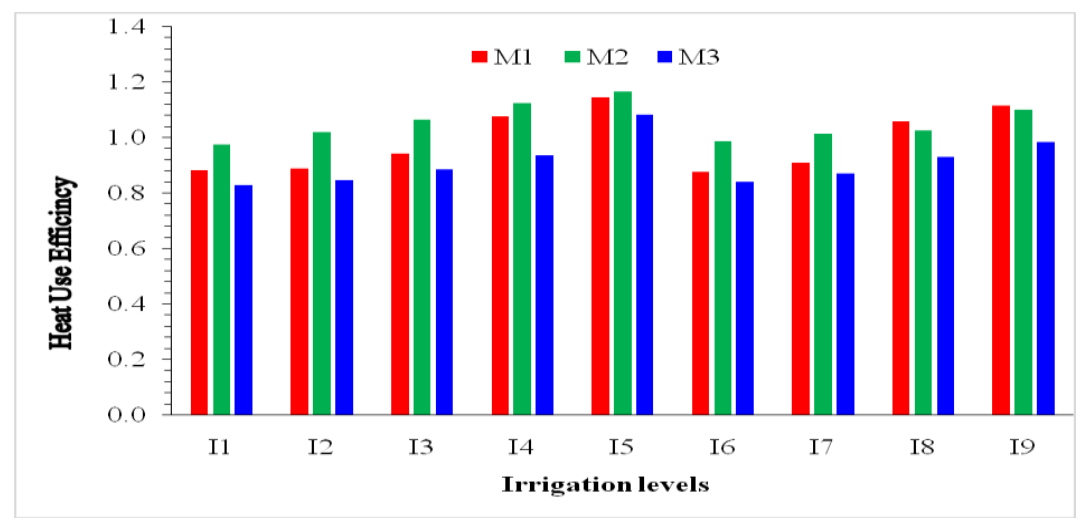

Fig.2 Heat use efficiency $\left(\mathrm{kg} \mathrm{ha}^{-1}{ }^{\circ} \mathrm{C}^{-1} \mathrm{day}^{-1}\right)$ as influenced by different dates of sowing and irrigation levels during 2016-17

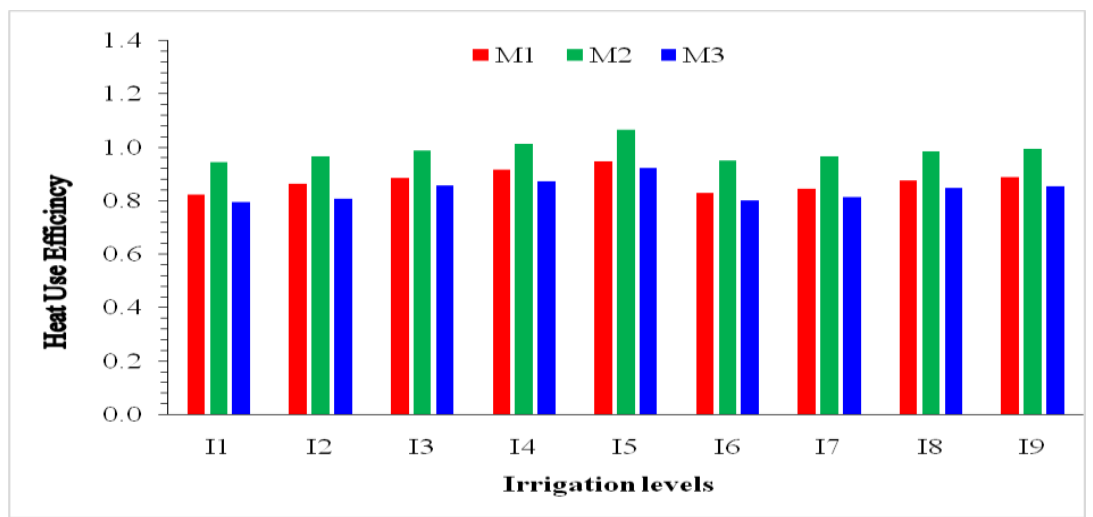

$\mathrm{T}_{1}=$ No irrigation

$\mathrm{T}_{2}=$ Irrigation with aerial water spray at pod filling stage (70-75 DAS) @ 5, $000 \mathrm{~L} \mathrm{ha}^{-1}$

$\mathrm{T}_{3}=$ Irrigation with aerial water spray at pod filling stage (70-75 DAS) @ 10, $000 \mathrm{~L} \mathrm{ha}^{-1}$

$\mathrm{T}_{4}=$ Irrigation with aerial water spray at pod filling stage (70-75 DAS) @ 15, $000 \mathrm{~L} \mathrm{ha}^{-1}$

$\mathrm{T}_{5}=$ Irrigation with aerial water spray at pod filling stage (70-75 DAS) @ 20, $000 \mathrm{~L} \mathrm{ha}^{-1}$

$\mathrm{T}_{6}=$ Irrigation with aerial water spray at maximum vegetative (35-40 DAS) and pod filling stages (70-75 DAS) @ $5,000 \mathrm{~L} \mathrm{ha}^{-1}$

$\mathrm{T}_{7}=$ Irrigation with aerial water spray at maximum vegetative (35-40 DAS) and Pod filling stages (70-75 DAS) @ $10,000 \mathrm{~L} \mathrm{ha}^{-1}$

$\mathrm{T}_{8}=$ Irrigation with aerial water spray at maximum vegetative (35-40 DAS) and pod filling stages (70-75 DAS) @ $15,000 \mathrm{~L} \mathrm{ha}^{-1}$

$\mathrm{T}_{9}=$ Irrigation with aerial water spray at Maximum vegetative (35-40 DAS) and Pod filling stages (70-75 DAS) @ $20,000 \mathrm{~L} \mathrm{ha}^{-1}$

It was revealed from the present investigation that, growing degree days required for a crop to attain maturity in two seasons differed considerably. The emergence of the crop required a range of 82 to $97 \mathrm{C}$ days. Application of deficit irrigation of $15,000 \mathrm{~L}$ $\mathrm{ha}^{-1}$ in $\mathrm{I}^{8}$ treatment and $20,000 \mathrm{~L} \mathrm{ha}^{-1}$ in $\mathrm{I}^{5}$ and $\mathrm{I}^{9}$ treatments influenced crop to accumulate more heat units to reach the next phenophase. Application of irrigation at maximum vegetative stage and pod filling stage had prolonged crop duration than 
application in the pod filling stage alone in $\mathrm{I}^{4}$ and $\mathrm{I}^{5}$ treatments. This might be due to deficit irrigation relieved part of stress accumulated in the vegetative stage and irrigation at pod filling further favored the extension of crop duration. Early sowing required more heat units to reach maturity than late sowing. These findings are in accordance with those of Gan et al., (2002); Agrawal and Upadhyay (2009). Chickpea cultivar JG-11 needed 782 to $1073 \mathrm{C}$ days to flower at Maddipadu village of Prakasam district. These findings are in agreement with those of Rajin et al., (2003) who concluded that chickpea phenological phases depend on accumulated thermal time and which varies with genotype. Heat use efficiency of chickpea during the 2015-16 crop season as influenced by dates of sowing and irrigation levels is presented in Fig-1. Heat use efficiency of chickpea was affected by the time of sowing and also irrigation levels.

Maximum heat use efficiency was recorded in the $1^{\text {st }}$ fortnight of November sowing with $1.05 \mathrm{~kg} \mathrm{ha}^{-1} \mathrm{C}^{-1}$ day $^{-1}$ followed by the $2^{\text {nd }}$ fortnight of October sowing with $0.99 \mathrm{~kg} \mathrm{ha}^{-1}$ $\mathrm{C}^{-1}$ day $^{-1}$. Among irrigation levels, the highest heat use efficiency of $1.13 \mathrm{~kg} \mathrm{ha}^{-1} \mathrm{C}^{-1}$ day $^{-1}$ was recorded with $\mathrm{I}_{5}$ treatment followed by $\mathrm{I}_{9}$ treatment $\left(1.07 \mathrm{~kg} \mathrm{ha}^{-1} \mathrm{C}^{-1}\right.$ day $\left.^{-1}\right)$ whereas, the lowest was observed in I1 treatment with 0.89 $\mathrm{kg} \mathrm{ha}^{-1} \mathrm{C}^{-1}$ day $^{-1}$.

The data on heat use efficiency during 201617 as presented in Fig-2 indicated that the highest heat use efficiency of $0.98 \mathrm{~kg} \mathrm{ha}^{-1} \mathrm{C}^{-1}$ day $^{-1}$ was recorded with $1^{\text {st }}$ fortnight of November sowing followed by $2^{\text {nd }}$ fortnight of October sowing with $0.87 \mathrm{~kg} \mathrm{ha}^{-1} \mathrm{C}^{-1}$ day $^{-1}$. Among different irrigation levels, the highest heat use efficiency was recorded in $\mathrm{I}_{5}$ treatment followed by $\mathrm{I}_{4}$ treatment, whereas the lowest was recorded with $\mathrm{I}_{1}$ treatment (0.85 kg ha ${ }^{-1} \mathrm{C}^{-1}$ day $\left.^{-1}\right)$.
It was revealed from the present investigation that heat use efficiency of was influenced by dates of sowing and irrigation levels. Delay in sowing led to decrease in heat use efficiency. These findings were in agreement with those of Venkatachalapathi and Reddy (2013); Agrawal et al., (2002).

\section{References}

Agrawal, K.K and Upadhyay, A.P. 2006. Effect of various irrigation under early and late planted chickpea (Cicer arietinum L.) In. Proceeding of National Seminar on Technological options for improving water productivity in Agriculture, JNKVV, Jabalpur, November 15-17. 208.

Agrawal, K.K and Upadhyay, A.P. 2009. Thermal indices for suitable sowing time of chickpea in Jabalpur region of Madhya Pradesh. Journal of Agrometeorology. 11(1): 89-91.

Agrawal, K.K., Upadhyay, A.P., Shanker, U and Gupta, V.K. 2002. Photothermal effect on growth, development and yield of chickpea (Cicer arietinum L.). Indian Journal of Agricultural Sciences.72(3): 169-70.

Ahmed, F., Islam, M.N., Jahan, M.A., Rahman, M.T and Ali, M.Z. 2011. Phenology, growth and yield of chickpea as influenced by weather variables under different sowing dates. Journal of Experimental Biosciences. 2(2): 83-88.

Basu, P.S., Ali, M and Chaturvedi, S.K. 2009. Terminal heat stress adversely affects hickpea productivity in northern India: Strategies to improve thermo tolerance in the crop under climate change. ISPRS Archives XXXVIII-8/W3 Workshop Proc.: Impact of Climate Change in Agriculture, December $17^{\text {th }}-18^{\text {th }}, 2009$, Ahemadabad, India.189-193.

Berger, J.D., Ali, M., Basu, P.S., Chaudhary, B.D., Chaturvedi, S.K., Deshmukh, P.S., Dharmara, J.P.S., Dwivedi, S.K., 
Gangadhar, G.C., Gaur, P.M., Kumar, J., Pannu, R.K., Siddique, K.H.M., Singh, D.N., Singh, D.P., Singh, S.J., Turner, N.C., Yadava, H.S and Yadav, S.S. 2006. Genotype by environment studies demonstrate the critical role of phenology in adaptation of chickpea (Cicer arietinum L.) to high and low yielding environments of India. Field Crops Research. 98: 230-244.

Chaitanya, S.K and Chandrika, V. 2006a. Performance of chickpea varieties under varied dates of sowing in Chittor district of Andhra Pradesh. Legume Research. 29(2): 137-139.

Gan, Y.T., Miller, P.R., Liu, P.H., Stevenson, F.C and Mc Donald, C.L. 2002. Seedling emergence, pod development, and seed yields of chickpea and dry pea in a semiarid environment. Canadian Journal of Plant Science. 82: 531-537.

Imtiaz, M., Malhotra S.R and Yadav, S.S. 2011. Genetic Adjustment to Changing Climates: Chickpea In: Yadav, S. S., Redden, J. R., Hatfield, L. J., Lotze Campen, $\mathrm{H}$ and Hall, E.A. (Eds.). Crop Adaptation to Climate Change. 251-268.

Jalota, S.K., Anil Sood and Harman, W.L. 2006. Assessing the response of chickpea (Ciceraeritinum L.) yield to irrigation water on two soils in Punjab (India): A simulation analysis using the CROPMAN model. Agricultural Water Management.79 (3): 312-320.

Mukesh, C., Dhananjai, S., Nishi, R., Vijay, K Singh R.B. 2010. Effect of growing degree days on chickpea production Bundelkhand region of Uttar Pradesh.
Journal of Food Legumes. 23(1):41-43.

Rajin, A. M., McKenzie, B.A and Hill, G.D. 2003. Phenology and growth response to irrigation and sowing date of kabuli chickpea (Cicer arietinum L.) in a cool temperature sub humid climate. Crops and Soils. 141: 3-4.

Sardar, R.G. 2009. Performance of chickpea (Cicer arietinum 1.) genotypes for green purpose to dates of sowing in northern transition zone of Karnataka. M.Sc. Thesis. Dharwad University of Agricultural Science. Dharwad (Karnataka).

Sugui, F.P and Sugui, C.C. 2002. Response of chickpea to dates of sowing in 110COSNorte, Philippines, International Chickpea and Pigeonpea Newsletter. 9: 1315.

Summerfield, R.J., Virmani, S.M., Robberts, E.H and Ellis, R.H. 1990. Adaptation of chickpea to agroclimatic constraints. In Chickpea in the Nineties. In: Proceedings of the $2^{\text {nd }}$ International Workshop on Chickpea Improvement (Eds. B. J. Walby\& S. D. Hall). ICRISAT, Patancheru, India. 61-72.

Venkatachalapathi, $\mathrm{V}$ and Reddy, M.V.S. 2013. Phenophase prediction model for chickpea (Cicer arietinum L.) growth using agrometeorological indices sown under different dates of sowing and number of irrigations in Anantapur District. Progressive Research. 8(2): 221-224.

Zinn, K.K., Tuncozdemir, $M$ and Harper, J.F. 2010. Temperature stress and plant sexual reproduction: uncovering the weakest links. Journal of Experimental Botany. 61: 19591968.

\section{How to cite this article:}

Medida Sunil Kumar, M. Martin Luther, Ch. Pulla Rao, K. L. Narasimha Rao and Ratna Prasad, P. 2020. Growing Degree Days and Heat Use Efficiency Influenced by Dates of Sowing and Irrigation Levels on Rainfed Chickpea. Int.J.Curr.Microbiol.App.Sci. 9(08): 39964002. doi: https://doi.org/10.20546/ijcmas.2020.908.460 